Огляди літератури, оригінальні дослідження, погляд на проблему, випадок з практики, короткі повідомлення УДК 616.37-002.2-008.64-06:616.379-008.64-06:616.72-018.3-007.248

DOI 10.11603/1811-2471.2020.v.i4.11506

\title{
ОСОБЛИВОСТІ СТАНУ ФУНКЦІОНАЛЬНОЇ НЕДОСТАТНОСТІ ПІДШЛУНКОВОї ЗАЛОЗИ ПРИ КОМОРБІДНОСТІ ХРОНІЧНОГО ПАНКРЕАТИТУ І ЦУКРОВОГО ДІАБЕТУ 2-ГО ТИПУ НА ТЛІ ПЕРВИННОГО ОСТЕОАРТРОЗУ
}

\author{
๑ І. М. Галабіцька, Л. С. Бабінець, Т. Р. Петрунько
}

Тернопільський національний медичний університет імені І. Я. Горбачевського МОЗ України

РЕзЮМЕ. Дослідження останніх років встановили значимий вплив стану підшлункової залози на перебіг коморбідної патології у пацієнтів із первинним остеоартрозом (ОА).

Мета - дослідити стан функціональної спроможності підшлункової залози (ПЗ) у пацієнтів із коморбідним перебігом хронічного панкреатиту (ХП) і цукрового діабету 2-го типу (ЦД 2) на тлі первинного остеоартрозу (ОА).

Матеріал і методи. Обстежено 117 пацієнтів із ХП на тлі первинного ОА із супутнім ЦД 2 та без нього. Основну групу склали 92 амбулаторних хворих з ХП тлі первинного ОА у поєднанні із ЦД 2 у фазі стійкої або нестійкої ремісії, групу порівняння - 25 хворих на ізольований ХП на тлі первинного ОА, а контрольну групу - 30 практично здорових осіб.

Результати. При коморбідності ХП і ЦД 2 на тлі первинного ОА екскреторна недостатність ПЗ була статистично значимо тяжчою, ніж у групі пацієнтів з ізольованим ХП, за вмістом фекальної а-еластази - відповідно $(110,35 \pm 1,81)$ мкг/г і $(159,56 \pm 4,15)$ мкг/г, що відповідало середньому і легкому ступеням екзокринної недостатності ПЗ відповідно, а за бальним показником копрограми - відповідно $(5,60 \pm 0,10)$ і $(3,89 \pm 0,16) 6$ блів $(p<0,05)$.

Висновки. При поєднаному перебігу ХП і ЦД 2 на тлі ОА кореляційний зв'язок між фекальною а-еластазою-1 і глікозильованим гемоглобіном був статистично значимо сильнішим, ніж у групі пацієнтів з ізольованим ХП, що свідчить про взаємообтяжувальний вплив ХП і ЦД 2.

КЛЮчОВІ СЛОВА: первинний остеоартроз; хронічний панкреатит; цукровий діабет 2-го типу.

Вступ. У результаті досліджень останніх років встановлено значимий вплив стану підшлункової залози на перебіг коморбідної патології у пацієнтів із первинним остеоартрозом (OA) [1]. Відомо, що основою ендокринних порушень при хронічному панкреатиті (ХП) $€$ морфологічні особливості розташування острівців серед ацинарної тканини, а не ізольовано від неї, що сприяє забезпеченню взаємодії між екзо- і ендокринними клітинами підшлункової залози (ПЗ) [1]. У зв'язку з особливостями кровопостачання ПЗ виділяють інсулоацинарну судинну систему. У ПЗ кровотік спрямований від острівців до екзокриннної тканини, що $\epsilon$ однією з основ функціональної взаємодії між ендо-та екзокринною тканинами, тобто гормони ПЗ впливають на ії̈ зовнішню секрецію, і навпаки [2]. Крім того, зміни у ПЗ хворих на ХП з цукровим діабетом другого типу (ЦД 2) часто відбуваються на тлі стеатопанкреатозу, що спричиняє прогресування ХП і ЦД 2 [3-5]. Таким чином, дослідження функціональної спроможності ПЗ при ХП у коморбідності з ЦД 2 на тлі ОА $є$ актуальним ще й з огляду на те, що пацієнти із таким поєднанням об'єднані наявністю у них метаболічного синдрому [1].

Мета - вивчити стан функціональної спроможності підшлункової залози у пацієнтів з коморбідним перебігом хронічного панкреатиту i цукрового діабету 2-го типу на тлі первинного остеоартрозу.
Матеріал і методи дослідження. Обстежено 117 пацієнтів із ХП на тлі первинного ОА з супутнім ЦД 2 та без нього. Основну групу склали 92 амбулаторних хворих з ХП тлі первинного ОА у поєднанні із ЦД 2 у фазі стійкої або нестійкої ремісії, групу порівняння - 25 хворих на ізольований ХП тлі первинного ОА, а контрольну групу - 30 практично здорових осіб. Групи порівняння були зіставними за віком, статтю, тривалістю і лікувальним комплексом на попередніх етапах. Середній вік обстежених склав $(47,54 \pm 9,51)$ років. Серед обстежених переважали жінки - 59,5 \%, чоловіків було 40,5\%, переважну більшість обстежених $(72,4$ \%) склали пацієнти працездатного віку - до 65 років включно. Середня тривалість ХП становила $(11,91 \pm 0,97)$ років, ОА - $(15,24 \pm 0,89)$ років, ЦД 2 - $(7,56 \pm 1,37)$. Діагнози ОА, ХП і ЦД 2 встановлювали за загальноприйнятими у світі критеріями і протоколами [4]. Оцінку наявності й глибини екскреторної недостатності (ЕкН) проводили за «золотим стандартом» - визначенням вмісту фекальної а-еластази-1 методом ІФА за допомогою стандартних наборів фірми BIOSERV ELASTASE 1-ELISA. Оцінку параметрів проводили за загальноприйнятими міжнародними стандартами (нормальна функція ПЗ без явищ ЕкH - >200 мкг/г) [5]. Аналіз копрограми проводили для визначення наявності ЕкН ПЗ і супутнього ентероколіту. Оцінку проводили за бальною шкалою, де за 1 бал враховували патологічні ознаки. Для діагностики інкреторної недостатності $(\mathrm{IHH})$ 
Огляди літератури, оригінальні дослідження, погляд на проблему, випадок з практики, короткі повідомлення

ПЗ використовували визначення рівня глюкози крові натще, глікозильованого гемоглобіну (HbA1c) (за допомогою набору для швидкого визначення НbA1с способом іонообмінної хроматографії) та індексу HOMA-IR, який розраховували за формулою:

HOMA = (глюкоза натще $($ ммоль/л) $\times$ інсулін натще (мкМО/л))/22,5.

Оцінку стану ПЗ проводили за параметрами ультразвукового дослідження (УЗД) ПЗ, які підсумовували для визначення ступеня тяжкості процесу за критеріями Марсельсько-Кембриджської класифікації ХП у балах.
Результати й обговорення. У таблиці 1 наведено дані щодо функціонального і структурного стану ПЗ у групах порівняння. Аналіз даних показав, що у середньому в контингенті обстежених хворих при коморбідному перебігу ОА, ХП і ЦД 2 ЕкН ПЗ була статистично значимо тяжчою, ніж у групі пацієнтів з ізольованим ХП на тлі ОА за вмістом фекальної а-еластази - відповідно $(109,25 \pm$ 1,21) мкг/г і $(163,39 \pm 3,45)$ мкг/г, що відповідало середньому і легкому ступеням ЕкН ПЗ відповідно у групах коморбідного з ЦД2 та ізольованого ХП на тлі OA $(p<0,001)$.

Таблиця 1. Порівняльний аналіз функціонального і структурного стану підшлункової залози у пацієнтів груп дослідження залежно від наявності цукрового діабету 2-го типу

\begin{tabular}{|c|c|c|c|}
\hline \multirow[b]{2}{*}{ Показник функціонального стану ПЗ } & \multicolumn{3}{|c|}{ Групи порівняння } \\
\hline & $\begin{array}{c}\text { група контролю } \\
(\mathrm{n}=30)\end{array}$ & $\begin{array}{c}\text { пацієнти з ХП } \\
(\mathrm{n}=25)\end{array}$ & $\begin{array}{c}\text { пацієнти з ХП і ЦД2 } \\
(\mathrm{n}=92)\end{array}$ \\
\hline а-еластаза, мкг/г & $245,63 \pm 6,28$ & $\begin{array}{c}163,39 \pm 3,45^{*} \\
\mathrm{P}_{2-3}<0,05\end{array}$ & $109,25 \pm 1,21 * *$ \\
\hline Глюкоза крові, ммоль/л & $4,78 \pm 0,08$ & $\begin{array}{c}5,47 \pm 0,21^{*} \\
\mathrm{P}_{2-3}<0,05\end{array}$ & $8,91 \pm 0,31 * *$ \\
\hline $\mathrm{HbA} 1 \mathrm{c}, \%$ & $4,55 \pm 0,10$ & $\begin{array}{c}5,64 \pm 0,12^{*} \\
\mathrm{P}_{2-3}<0,05\end{array}$ & $7,75 \pm 0,12^{* *}$ \\
\hline Індекс НОМА & $1,46 \pm 0,09$ & $\begin{array}{l}1,43 \pm 0,07 \\
p_{2-3}<0,05\end{array}$ & $3,27 \pm 0,06 * *$ \\
\hline Бальний показник копрограми, бали & $0,09 \pm 0,02$ & $\begin{array}{c}3,69 \pm 0,14^{*} \\
\mathrm{p}_{2-3}<0,05\end{array}$ & $5,62 \pm 0,11 * *$ \\
\hline Бальний УЗ-показник структури ПЗ & $1,05 \pm 0,03$ & $3,99 \pm 0,68 *$ & $6,22 \pm 0,66 * *$ \\
\hline
\end{tabular}

Примітки:1. * - вірогідна відмінність показників стосовно таких групи контролю $\left(p_{1-2}<0,05\right)$;

2. ** - вірогідна відмінність показників стосовно таких у групі з ізольованим ХП на тлі $O A\left(p_{1-3}<0,05\right)$.

Для виявлення розладів екскреторної функції ПЗ було також використано недорогий, проте інформативний аналіз - копрограму, яку оцінювали в балах. Встановили статистично значимо вищий рівень вказаного показника у пацієнтів з ХП із ЦД 2, порівняно з таким показником у пацієнтів з ізольованим ХП на тлі ОА (відповідно $(5,60 \pm 0,10)$ i $(3,89 \pm 0,16)$ балів $(p<0,05))$. Також був проведений кореляційний і регресійний аналіз між показниками фекальної а-еластази-1 та глікозильованого гемоглобіну, який показав наявність статистично значимих високої сили негативних зв'язків у обох досліджуваних групах ( $<<0,05)$, у групі пацієнтів 3 ОА і ХП без ЦД 2 - г=-0,568, а у групі пацієнтів з ОА, ХП і ЦД2 - г=-0,791 (р<0,05) (рис. 1, 2).

У результаті проведеного аналізу було виявлено, що у групі пацієнтів з ХП і ЦД 2 на тлі ОА кореляційний зв'язок був статистично значимо сильнішим, ніж у групі пацієнтів із ізольованим ХП, що свідчить про взаємообтяжувальний вплив перебігу ХП і ЦД 2.

Висновки. 1. При коморбідності ХП і ЦД 2 на тлі первинного ОА екскреторна недостатність ПЗ була достовірно тяжчою, ніж у групі пацієнтів з ізо- льованим ХП, за вмістом фекальної а-еластази відповідно $(110,35 \pm 1,81)$ мкг/г і $(159,56 \pm 4,15)$ мкг/г, що відповідало середньому і легкому ступеням ЕкН ПЗ відповідно, а за бальним показником копрограми - відповідно $(5,60 \pm 0,10)$ і $(3,89 \pm 0,16)$ балів $(p<0,05)$.

2. Виявлено статистично значимий високої сили негативний зв'язок між параметрами фекальної а-еластази-1 і глікозильованого гемоглобіну в обох досліджуваних групах $(p<0,05)$ : при ХП на тлі ОА без ЦД 2 - г=-0,568, при коморбідності ХП і ЦД 2 - r=-0,791 ( $<<0,05)$, що довело достовірний взаємовплив стану екскреторної та інкреторної функцій підшлункової залози.

3. При поєднаному перебігу ХП і ЦД 2 на тлі ОА кореляційний зв'язок між фекальною а-еластазою-1 і глікозильованим гемоглобіном був статистично значимо сильнішим, ніж у групі пацієнтів із ізольованим ХП, що свідчить про взаємообтяжувальний вплив ХП і ЦД 2.

Перспективи подальших досліджень полягають у розробці й обґрунтуванні комплексних програм лікування пацієнтів із коморбідним перебігом ХП і ЦД 2 на тлі первинного ОА. 
Огляди літератури, оригінальні дослідження, погляд на проблему, випадок з практики, короткі повідомлення

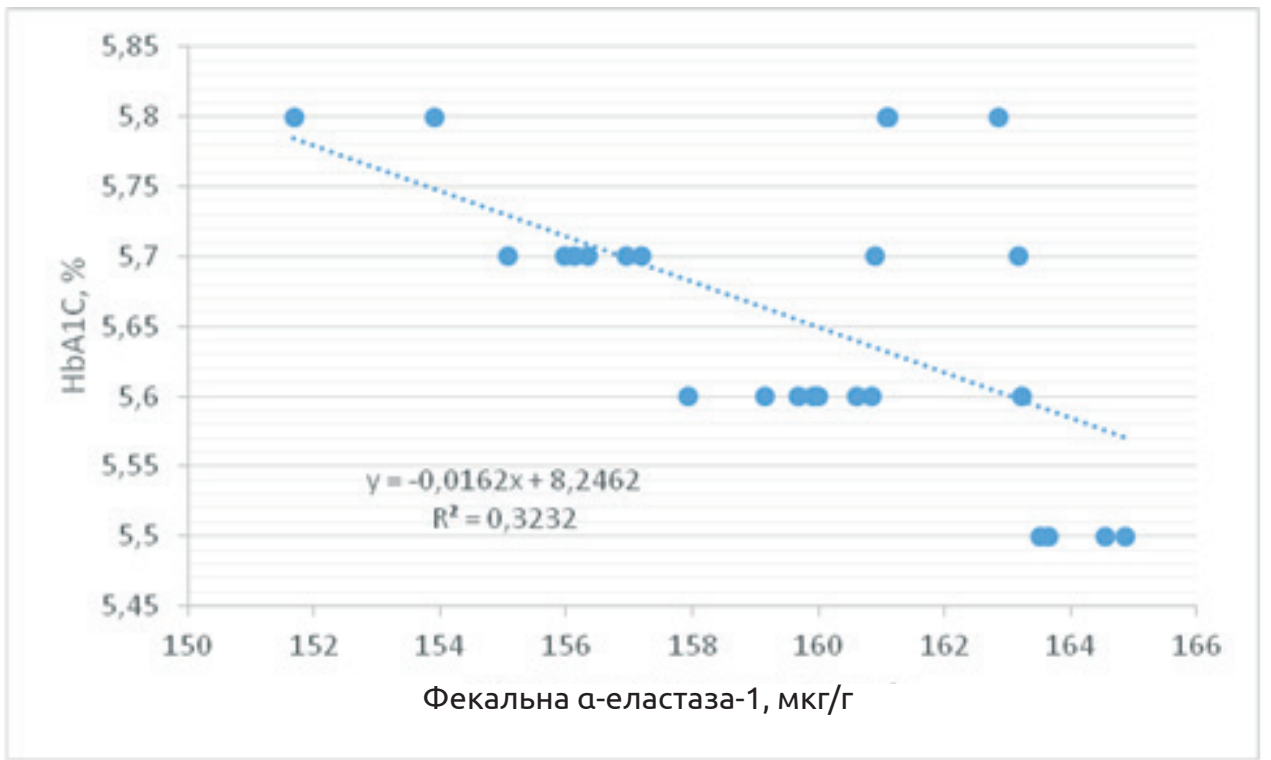

Рис. 1. Взаємоз'язок між фекальною а-еластазою-1 та глікозильованим гемоглобіном у пацєнтів з ізольованим хронічним панкреатитом на тлі остеоартриту.

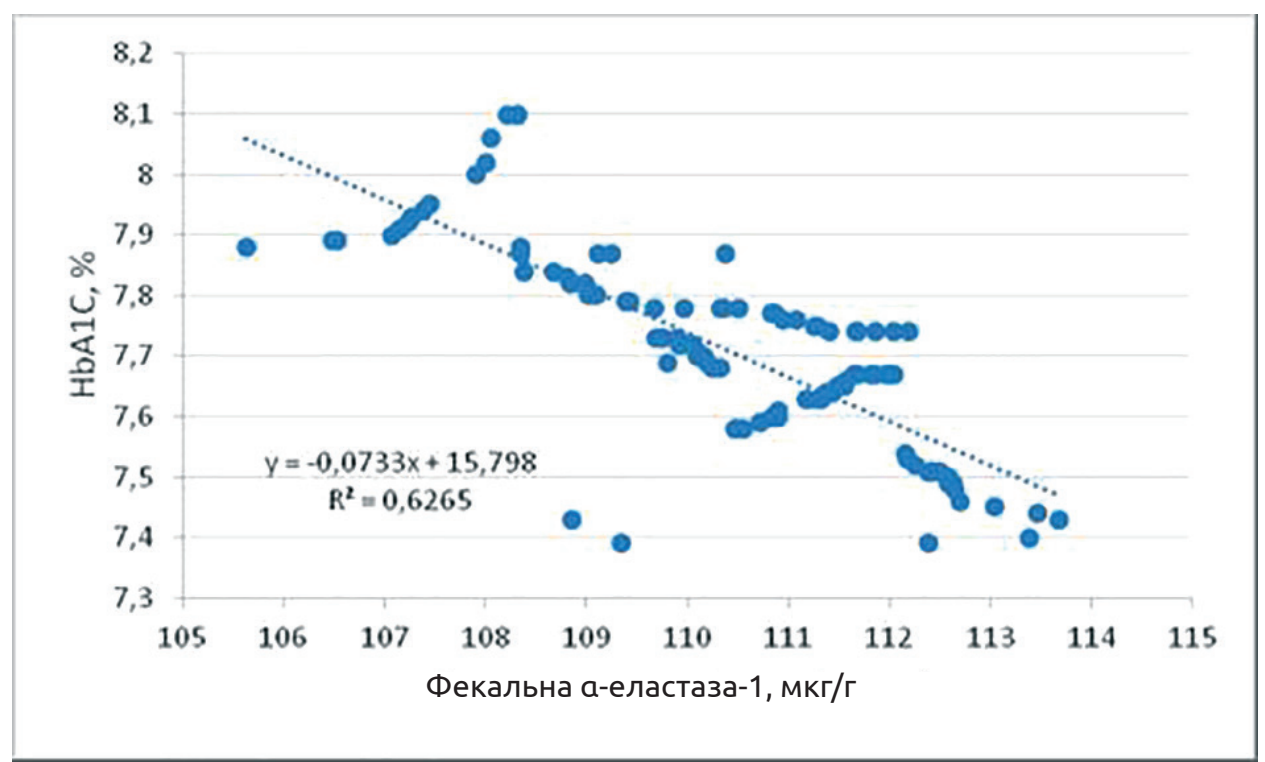

Рис. 2. Взаємоз'язок між фекальною а-еластазою-1 та глікозильованим гемоглобіном у пацєнтів з хронічним панкреатитом і цукровим діабетом 2-го типу на тлі остеоартриту.

\section{ЛITEPATУРA}

1. Babinets L. S. Chronic inflammatory process and bone tissue changes in patients with osteoarthritis and exocrine pancreatic insufficiency / L. S. Babinets, I. M. Halabitska // Lekarsky Obzor. - 2020. - No. 69 (1). - P. 7-10.

2. The Impact of risk factors of chronic pancreatitis on secretin pancreatic function testing: results of a 20-year study / D. Kothari, G. Ketwaroo, S. D. Freedman, S. G. Sheth // Pancreas. - 2017. - Vol. 46 (7). - P. 887-890.

3. Epidemiology of chronic pancreatitis: burden of the disease and consequences / P. Levy, E. Dominguez-
Munoz, C. Imrie [et al.] // United Eur. Gastroenterol. J. 2014. - Vol. 2 (5). - P. 345-354.

4. Lew D. Chronic pancreatitis: current status and challenges for prevention and treatment / D. Lew, E. Afghani, S. Pandol // Dig. Dis. Sci. - 2017. - Vol. 62 (7). P. 702-1712.

5. Lohr J. M. Synopsis of recent guidelines on pancreatic exocrine insufficiency / J. M. Lohr, M. R. Oliver, L. Frulloni // United Eur. Gastroenterol. J. - 2013. Vol. I 2). - P. 79-83. 
Огляди літератури, оригінальні дослідження, погляд на проблему, випадок з практики, короткі повідомлення REFERENCES

1. Babinets, L.S., \& Halabitska, I.M. (2020). Chronic inflammatory process and bone tissue changes in patients with osteoarthritis and exocrine pancreatic insufficiency. Lekarsky Obzor, 69 (1), 7-10.

2. Kothari, D., Ketwaroo, G., Freedman, S.D., \& Sheth, S.G. (2017). The Impact of risk factors of chronic pancreatitis on secretin pancreatic function testing: results of a 20-year study. Pancreas, 46 (7), 887-890. DOI: 10.1097/MPA.0000000000000871.

3. Levy, P., Dominguez-Munoz, E., Imrie, C., Lohr, M., \& Maisonneuve, P. (2014). Epidemiology of

chronic pancreatitis: burden of the disease and consequences. United Eur. Gastroenterol. J., 2 (5), 345-54. DOI: $10.1177 / 2050640614548208$.

4. Lew, D., Afghani, E., \& Pandol, S. (2017). Chronic pancreatitis: current status and challenges for prevention and treatment. Dig. Dis. Sci., 62 (7), 1702-1712. DOI: 10.1007/sl0620- 017-4602-2.

5. Lohr, J.M., Oliver, M.R., \& Frulloni, L. (2013). Synopsis of recent guidelines on pancreatic exocrine insufficiency. United Eur. Gastroenterol. J., I (2), 79-83. DOI: $10.1177 / 2050640613476500$.

\title{
ОСОБЕННОСТИ СОСТОЯНИЯ ФУНКЦИОНАЛЬНОЙ НЕДОСТАТОЧНОСТИ ПОДЖЕЛУДОЧНОЙ ЖЕЛЕЗЫ ПРИ КОМОРБИДНОСТИ ХРОНИЧЕСКОГО ПАНКРЕАТИТА И САХАРНОГО ДИАБЕТА 2-ГО ТИПА НА ФОНЕ ПЕРВИЧНОГО ОСТЕОАРТРОЗА
}

\author{
○И. М. Галабицкая, Л. С. Бабинец, Т. Р. Петрунько
}

Тернопольский национальный медицинский университет имени И. Я. Горбачевского МОз Украины

РЕзЮМЕ. Недавние исследования показали значительное влияние состояния поджелудочной железы на течение сопутствующей патологии у пациентов с первичным остеоартритом (ОА).

Цель - исследовать состояние функциональной способности поджелудочной железы (Пж) у пациентов с коморбидным течением хронического панкреатита и сахарного диабета 2-го типа (СД 2) на фоне первичного остеоартроза.

Материал и методы. Обследовано 117 пациентов с ХП на фоне первичного ОА с сопутствующим СД 2 и без него. Основную группу составили 92 амбулаторных больных с ХП фоне первичного ОА в сочетании с СД 2 в фазе стойкой или нестойкой ремиссии, группу сравнения - 25 больных с изолированным ХП фоне первичного ОА, а контрольную группу - 30 практически здоровых лиц.

Результаты. При коморбидности ХП и СД 2 на фоне первичного ОА экскреторная недостаточность ПО была статистически значимо тяжелее, чем в группе пациентов с изолированным ХП, по содержанию фекальной а-эластазы - соответственно $(110,35 \pm 1,81)$ мкг/г и $(159,56 \pm 4,15)$ мкг/г, что соответствовало средней и легкой степеням ексреторной недостаточности ПЖ соответственно, а по бальным показателем копрограммы - соответственно $(5,60 \pm 0,10)$ и $(3,89 \pm 0,16)$ баллов $(p<0,05)$.

Выводы. При совместном течении ХП и СД 2 на фоне ОА корреляционная связь между фекальной а-эластазой-1 и гликозилированным гемоглобином была статистически значимо сильнее, чем в группе пациентов с изолированным ХП, что свидетельствует об усугубляющем влиянии ХП и СД 2.

КЛЮчЕВЫЕ СЛОВА: первичный остеоартроз; хронический панкреатит; сахарный диабет 2 типа.

\section{PECULIARITIES OF THE CONDITION OF FUNCTIONAL INSUFFICIENCY OF THE PANCREAS IN THE COMORBIDITY OF CHRONIC PANCREATITIS AND TYPE 2 DIABETES MELLITUS ON THE BACKGROUND OF PRIMARY OSTEOARTHRITIS}

\section{@I. M. Halabitska, L. S. Babinets, T. R. Petrunko \\ I. Horbachevsky Ternopil National Medical University}

SUMMARY. Recent studies have shown a significant effect of pancreatic conditions on the course of comorbid pathology in patients with primary osteoarthritis.

The aim - to study the state of functional capacity of the pancreas in patients with comorbid chronic pancreatitis and type 2 diabetes mellitus on the background of primary osteoarthritis.

Material and Methods. 117 patients with CP on the background of primary OA with concomitant diabetes mellitus and without it were studied. The main group consisted of 92 outpatients with CP on the background of primary OA in combination with diabetes mellitus in the phase of stable or unstable remission, the comparison group - 25 patients with isolated CP on the background of primary OA, and the control group - 30 healthy individuals.

Results and Discussion. With the comorbidity of CP and diabetes mellitus on the background of primary OA, the excretory insufficiency of the pancreas was significantly more severe than in the group of patients with isolated CP, the content of fecal a-elastase - respectively $(110.35 \pm 1.81) \mu \mathrm{g} / \mathrm{g}$ and $(159.56 \pm 4.15) \mu \mathrm{g} / \mathrm{g}$, which corresponded to the average and mild degrees of excretory insufficiency of the pancreas, respectively, and the score of the coprogram - respectively $(5.60 \pm 0.10)$ and $(3.89 \pm 0.16)$ points $(p<0,05)$.

Conclusions. In the combined course of CP and diabetes mellitus on the background of OA, the correlation between fecal a-elastase-1 and glycosylated hemoglobin was statistically significantly stronger than in the group of patients with isolated CP, indicating a mutual burden of CP and diabetes mellitus.

KEY WORDS: primary osteoarthritis; chronic pancreatitis; type 2 diabetes mellitus. 